\title{
A Five-Year Climatology of Elevated Severe Convective Storms in the United States East of the Rocky Mountains
}

\author{
KATHERINE L. HORGAN* \\ National Weather Center Research Experiences for Undergraduates, Norman, Oklahoma, and North Carolina State University, \\ Raleigh, North Carolina \\ DAVID M. SCHULTZ ${ }^{+}$ \\ Cooperative Institute for Mesoscale Meteorological Studies, University of Oklahoma, and NOAA/National Severe Storms Laboratory, \\ Norman, Oklahoma \\ John E. HALES JR. AND STEPHen F. CORFIDI \\ NOAA/NWS/NCEP/Storm Prediction Center, Norman, Oklahoma \\ ROBERT H. JOHNS \\ Norman, Oklahoma
}

(Manuscript received 1 June 2006, in final form 28 September 2006)

\begin{abstract}
A 5-yr climatology of elevated severe convective storms was constructed for 1983-87 east of the Rocky Mountains. Potential cases were selected by finding severe storm reports on the cold side of surface fronts. Of the 1826 days during the 5-yr period, 1689 (91\%) had surface fronts east of the Rockies. Of the 1689 days with surface fronts, $129(8 \%)$ were associated with elevated severe storm cases. Of the 1066 severe storm reports associated with the 129 elevated severe storm cases, 624 (59\%) were hail reports, $396(37 \%)$ were wind reports, and $46(4 \%)$ were tornado reports. A maximum of elevated severe storm cases occurred in May with a secondary maximum in September. Elevated severe storm cases vary geographically throughout the year, with a maximum over the south-central United States in winter to a central and eastern U.S. maximum in spring and summer. A diurnal maximum of elevated severe storm cases occurred at 2100 UTC, which coincided with the diurnal maximum of hail reports. The wind reports had a broad maximum during the daytime. Because the forecasting of hail from elevated storms typically does not pose as significant a forecast challenge as severe wind for forecasters and tornadoes from elevated storms are relatively uncommon, this study focuses on the occurrence of severe wind from elevated storms. Elevated severe storm cases that produce only severe wind reports occurred roughly 5 times a year. To examine the environments associated with cases that produced severe winds only, five cases were examined in more detail. Common elements among the five cases included elevated convective available potential energy, weak surface easterlies, and shallow near-surface stable layers (less than $100 \mathrm{hPa}$ thick).
\end{abstract}

\footnotetext{
* Current affiliation: Atmospheric Science Group, Department of Geosciences, Texas Tech University, Lubbock, Texas.

+ Current affiliation: Division of Atmospheric Sciences, Department of Physical Sciences, University of Helsinki, and Finnish Meteorological Institute, Helsinki, Finland.
}

Corresponding author address: Dr. David M. Schultz, NOAA/National Severe Storms Laboratory/FRDD, Ste. 4356, 120 David L. Boren Blvd., Norman, OK 73072-7326.

E-mail: david.schultz@noaa.gov

DOI: 10.1175/WAF1032.1

(C) 2007 American Meteorological Society 


\section{Introduction}

Deep moist convection can be either surface based or elevated. Surface-based convection occurs when nearsurface air is the most unstable air parcel in the column. Elevated convection occurs above a near-surface stable layer, such that the most-unstable parcel is above the surface. Recent research has shown that elevated convective storms may be relatively common. For example, Wilson and Roberts (2006) found that half of the convective storms during the International $\mathrm{H}_{2} \mathrm{O}$ Project were elevated. Recent papers also argue for a greater understanding of the processes that initiate elevated convection (e.g., Dabberdt et al. 2005).

Means (1952) may have been the first to recognize the importance of elevated convection by presenting conceptual models of thunderstorms on the cold sides of fronts (see his Figs. 21-23) and by stating, "The surface chart is less representative than the $850-\mathrm{mb}$. chart because summer showers and thunderstorms in the Midwest are primarily higher level phenomena. The lower portion of the stable layer is frequently near the 850-mb. level. Unfortunately such summer thunderstorm and precipitation patterns do not correspond well to classical concepts of precipitation around frontal cyclones" (Means 1952, p. 181).

Colman (1990a,b) was the first to provide detailed documentation of the widespread occurrence of elevated thunderstorms in the United States. Colman's (1990a) climatology revealed that elevated deep convection typically occurs north of a surface warm front in an environment of strong baroclinity, large vertical wind shear, and warm-air advection. His climatology also showed that nearly all cool-season storms are elevated, and a smaller proportion of warm-season storms are elevated. Colman (1990a, 1991) argued that nearly half of the elevated thunderstorms from his climatology formed in the absence of conditional instability, although Williams (1991) disagreed with that assessment. Case studies of elevated convection by Rochette and Moore (1996), Rochette et al. (1999), and Moore et al. (1998, 2003) focused on elevated convective storms that produce heavy rainfall, finding they were associated with elevated instability.

Sometimes elevated convection produces severe weather in the form of large hail, strong winds, and/or tornadoes (e.g., Branick et al. 1988; Colman 1990b; Schmidt and Cotton 1989; Bernardet and Cotton 1998; Banacos and Schultz 2005). Grant (1995) examined 11 cases of elevated convection producing severe weather occurring between April 1992 and April 1994. The environments of these cases possessed convective instability above a shallow, but strong, inversion. Of the 321 severe reports associated with these 11 cases, he found that $92 \%$ were hail, $7 \%$ were wind, and $1 \%$ were tornadoes. Although Grant (1995) provided a preliminary analysis of elevated severe convection, a more thorough study that examines when, where, and how often elevated convection produces severe weather does not exist.

Operational experience at the National Weather Service's (NWS's) Storm Prediction Center (SPC) confirms the results of Grant (1995), indicating that the primary threat with elevated storms is severe hail. Because the ingredients associated with hail are similar regardless of whether a storm is elevated or surface based, the forecasting of hail from elevated storms typically does not pose as significant a forecast challenge as severe wind for SPC forecasters. Because the nearsurface stable layer limits the potential for tornadoes (e.g., Fritsch and Forbes 2001, p. 339), tornadoes from elevated storms are rare (e.g., Grant 1995). In contrast, severe surface wind from elevated storms occurs somewhat more frequently. Knowledge of the factors that affect the production of severe surface winds from elevated storms, however, is limited. Consequently, elevated storms producing severe surface winds remain problematic for forecasters.

The purpose of this paper is twofold. First, we extend Grant's (1995) work by creating a 5-yr climatology of severe-weather-producing elevated convection. Second, we explore the synoptic environments favoring elevated convection that produce severe wind at the surface. Section 2 of this paper details the data and methodology used to construct the climatology. The geographical, annual, and diurnal distributions of severe-weather-producing elevated convection are presented in section 3. Section 4 presents five case studies in which elevated storms produce severe surface winds. Section 5 raises unanswered questions about elevated severe wind cases, and section 6 concludes this paper.

\section{Data and methodology}

To assess the environments that cause elevated convection producing severe weather, a climatology was created containing possible elevated severe storm cases across the contiguous United States from the Front Range of the Rockies eastward to the Atlantic coast for 1983-87. These five calendar years were chosen for two main reasons. First, the years were selected to maximize the number of National Meteorological Center (NMC; now known as the National Centers for Environmental Prediction) manually analyzed 3-h surface maps archived on microfilm at the SPC. Using these maps avoided the perceived degradation in the quality of the surface analyses in later years from the switch to 
automated isobar analysis (e.g., Bosart 1989; Corfidi and Comba 1989, p. 344; Mass 1991) and surface frontal analyses performed by less experienced analysts. Second, a dramatic increase in severe reports for wind (Weiss et al. 2002; Doswell et al. 2005), hail (Schaefer et al. 2004; Doswell et al. 2005), and tornadoes (Doswell et al. 2005; Verbout et al. 2006) has occurred over time. Thus, the climatology will be dependent upon our choice of years. By using severe reports from the 1980s, the inflation in the number of severe reports in recent years, many of which were of marginal intensity, is less of a problem.

Severe reports were defined using the NWS criteria of hail 0.75 in. $(1.9 \mathrm{~cm})$ or greater in diameter, wind gusts of at least $50 \mathrm{kt}\left(26 \mathrm{~m} \mathrm{~s}^{-1}\right)$, or tornadoes (e.g., Johns and Doswell 1992). Significant severe weather was defined by Hales (1988) as hail 2 in. $(5.1 \mathrm{~cm})$ or greater in diameter, wind gusts of at least $65 \mathrm{kt}$ (33 $\mathrm{m} \mathrm{s}^{-1}$ ), or tornadoes with F2 intensity or greater. Both severe reports and significant severe reports were examined in this climatology of elevated severe weather cases.

Identifying elevated severe weather cases for the climatology consisted of two steps. This two-step technique mimics the methodology used in forecasting elevated convection during operations at the SPC. The first step was to examine the daily 1200 UTC surface maps in the weekly National Oceanic and Atmospheric Administration (NOAA) publication Daily Weather Maps for any analyzed surface fronts. If a surface front was found, the National Climatic Data Center's publication Storm Data was examined to determine whether any severe reports occurred on the cold side of the surface front. Of the 1826 days during the 5-yr period, 1689 (91\%) had surface fronts east of the Rockies. Of these 1689 days with surface fronts, 394 (23\%) had potential elevated severe storm cases associated with them.

The second step was to take the 394 potential elevated severe storm cases and apply two more criteria to determine if the cases were indeed elevated. The first criterion was that the severe reports needed to be at least $1^{\circ}$ latitude $(111 \mathrm{~km})$ on the cold side of the surface front. This criterion was used to help ensure that the reports occurred sufficiently far enough into the cold air to be elevated. NMC's 3-h manually analyzed surface maps on microfilm were examined to determine the location of the front around the time the severe reports occurred. This criterion focuses on convection occurring in association with surface frontal boundaries and tends to exclude convection that may be occurring above a surface-based nocturnal inversion.

The second criterion was to examine proximity soundings for possible lower-tropospheric stable layers. The proximity sounding had to be on the cold side of the front, no more than $3^{\circ}$ latitude $(333 \mathrm{~km})$ away from the reports, and within $3 \mathrm{~h}$ of the initial report. Our criteria are comparable to previously published studies of severe wind climatologies. Coniglio et al. (2004) used $300 \mathrm{~km}$ and no time frame, whereas Burke and Schultz (2004) used $300 \mathrm{~km}$ and $5 \mathrm{~h}$ for their climatologies of derechos and cold-season bow echoes, respectively. Harnack et al.'s (1997) study of warm-season wind events in Utah used criteria of $170 \mathrm{~km}$ and $3 \mathrm{~h}$ after the nominal sounding time. If the initial report was more than $3 \mathrm{~h}$ from sounding times, both of the soundings surrounding the time of the initial report were examined. If the report was on the cold side of the front and the proximity sounding possessed a low-level stable layer, this case was considered to be a probable elevated severe case. The case was also given a subjective ranking from 1 to 10 on both the confidence of being elevated and the availability of appropriate proximity soundings. A case with low confidence $(<5)$ typically had no most-unstable convective available potential energy (MUCAPE) in its proximity soundings, a small number of severe reports, no proximity soundings near the reports, and/or its associated severe reports were less than $111 \mathrm{~km}$ from the front. A further complication occurred if the 1200 UTC proximity sounding possessed a lower-tropospheric stable layer (such as a nocturnal radiational inversion), but the 0000 UTC proximity sounding did not possess such a stable layer. If the severe report occurred between these two times, the case was assigned a low confidence value, as it was unclear whether the convection would have been elevated. A case with high confidence $(>8)$ had a stable layer in its proximity soundings, its associated severe reports more than $111 \mathrm{~km}$ on the cold side of the front, and/or more than 10 severe reports associated with it. Of the 394 potential elevated severe storm cases, 129 (33\%) were considered elevated severe storm cases by these confidence criteria. Thus, of the 1689 days with surface fronts, 129 (8\%) were considered elevated severe storm cases for the purposes of this paper, an order of magnitude greater than the 11 cases in Grant (1995).

\section{Climatology}

This 5-yr climatology resulted in 129 elevated severe storm cases with 1066 severe reports. Of the 1066 severe reports, 624 (59\%) were hail, 396 (37\%) were wind, and 46 (4\%) were tornadoes (Fig. 1). Compared with Grant's (1995) dataset, our dataset has a much larger percentage of wind reports (37\% versus $7 \%$ ) and a slightly larger percentage of tornado reports (4\% ver- 


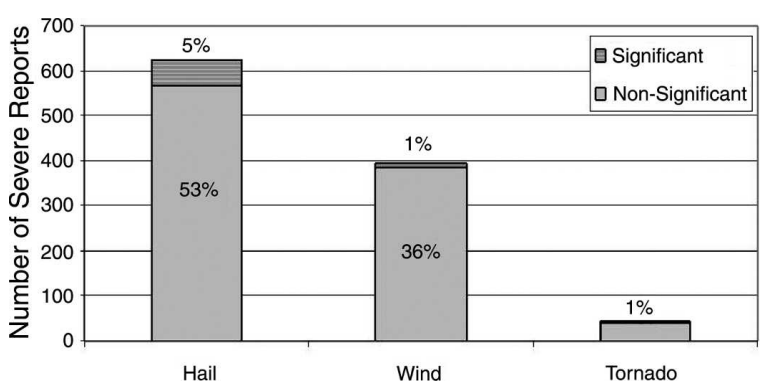

FIG. 1. Distribution of 1066 severe storm reports for the 129 elevated severe storm cases in the climatology by type of severe weather. The striped part of each bar indicates significant-severe reports.

sus $1 \%)$. The reasons for these differences are unclear, but may be related to the differing methodologies between the two studies, the different years from which cases were obtained, the much smaller sample size in Grant's (1995) study, and the evolving nature of the severe weather database, as discussed in the last section. Evidence for this last effect being quite important is that Grant's 11 cases produced 321 severe reports $(29$ reports per case), whereas our 129 cases produced 1066 severe reports (8 reports per case).

Of the 1066 severe reports, $73(7 \%)$ were significant severe reports. Of the 624 hail reports, $58(9 \%)$ were significant severe reports, whereas only $10(3 \%)$ of the 396 wind reports were significant severe reports. Of the 46 tornado reports, $5(10 \%)$ were significant severe reports. This compares with the $7.5 \%$ of hail, $13.6 \%$ of wind, and $25 \%$ of tornadoes during 1970-2004 that are significant from all storms (D. McCarthy 2006, personal communication). Clearly, elevated convection is less likely to produce significant wind and tornado reports than convection in general, whereas the percent of significant hail is approximately the same for the elevatedstorm and all-storm datasets. These results are consistent with SPC forecaster experience with elevated convection (as noted by coauthors JEH, SFC, and RHJ).

Elevated severe storm cases occurred most often across and just east of the Great Plains (Fig. 2). Nebraska had 19 elevated severe storm cases, 5 more than any other state (Fig. 2). Florida, Illinois, and much of coastal New England had no occurrences of elevated severe storm cases during 1983-87. Elevated severe storm cases possessed an annual cycle (Fig. 3). In the spring, elevated severe storm cases occurred across much of the central and eastern United States (Fig. 3a). During summer, the maximum of elevated severe storm cases occurred over the central United States with less activity in the southern United States (Fig. 3b). In the fall, a maximum of elevated severe storm cases occurred in September over the central United States, but

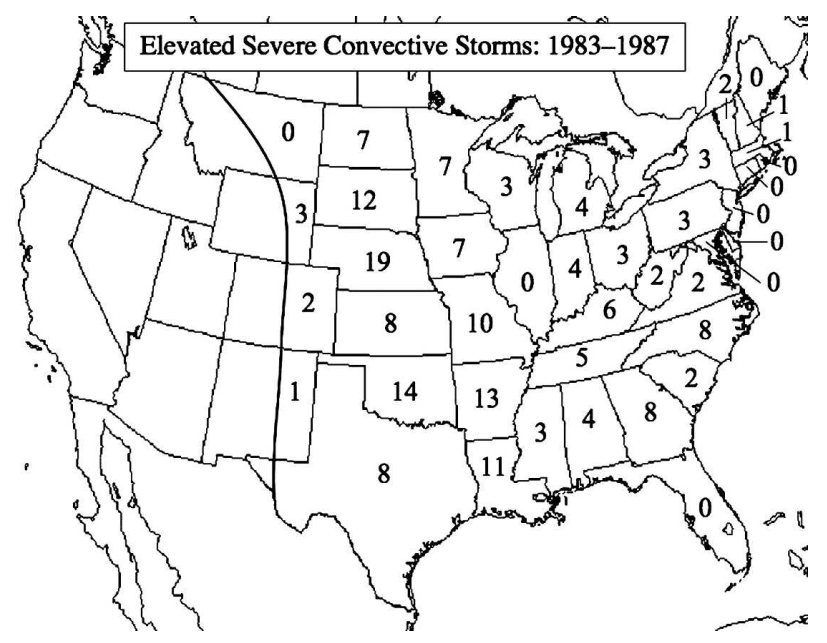

FIG. 2. Total number of elevated severe storm cases by state across the contiguous United States from the Front Range of the Rocky Mountains eastward to the Atlantic coast for 1983-87. The black line along the Front Range of the Rocky Mountains represents the approximate western edge of the domain. Events that occurred in more than one state were counted multiple times, once for each state.

elevated severe storm cases also occurred over the southeast United States in October and November (Fig. 3c). During the winter, the elevated severe storm cases were concentrated over the southern United States from Texas to South Carolina, particularly in the south-central states (Fig. 3d). These results are similar to Colman's (1990a, his Fig. 3) annual cycle of elevated thunderstorms.

The 129 elevated severe storm cases had a springtime maximum in May with a secondary maximum in September (Fig. 4a), which Colman (1990a) attributed to an early fall storm track. This distribution looks nearly identical to Colman's (1990a, his Fig. 4) 5-yr climatology of elevated thunderstorms, indicating a close relationship between the frequencies of both occurrences. The 45 hail-only cases had a similar distribution to the total of all elevated severe storm cases with the same May and September maxima (Fig. 4b), and the 26 windonly cases had a maximum in February with a second maximum in July (Fig. 4c). Twice as many hail-only cases existed as compared to wind-only cases, which explains the similarity between the distribution of all cases and the distribution of hail-only cases.

Elevated severe storm cases have diurnal, as well as seasonal, variations (Fig. 5). Of the 129 elevated severe storm cases, the initial reports from the 34 (26\%) wind/ hail cases and the 45 (35\%) hail-only cases had maxima at 2100 UTC (Figs. 5b and 5d). These results are similar to the distribution of all elevated severe storm initial reports (Fig. 5a) because of the abundance of hail re- 

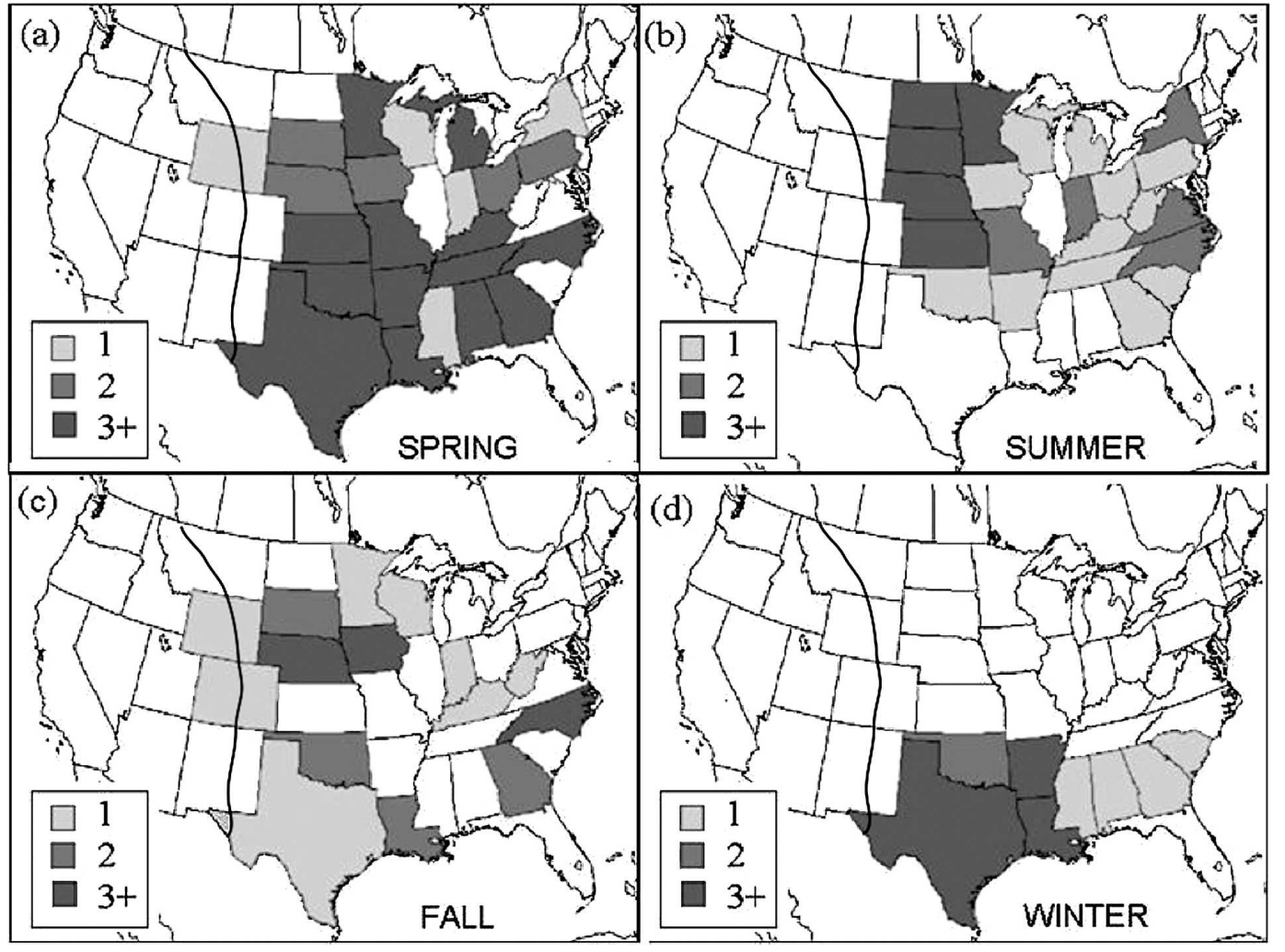

FIG. 3. Seasonal distribution of elevated severe storm cases. Shades of gray indicate the number of cases for a given state during the designated season. Black line along the Front Range of the Rocky Mountains represents the approximate western edge of the domain. Seasons are defined as (a) spring (March-May), (b) summer (JuneAugust), (c) fall (September-November), and (d) winter (December-February).

ports. The initial reports from the $26(20 \%)$ wind-only cases had a broad daytime maximum of $1300-0000$ UTC (Fig. 5c).

\section{Environments of elevated severe storm wind-only cases}

As previously discussed in section 1 , forecasting severe wind occurrence from elevated storms is challenging. In this section, we explore the environments in which severe wind occurs from elevated storms. There were 26 cases that were associated with only wind reports (Fig. 4c), leading to an average of roughly 5 cases per year. The 26 wind-only cases obtained through the climatology were scrutinized independently by two coauthors (KLH and JEH) for their veracity. This scrutiny resulted in five cases that were rated with high confidence levels (rating of 7 or greater) and were associated with only wind reports. These five cases are the focus of the remainder of this paper and are presented, not in chronologic order, but in an order that illustrates the similarities and differences between them. Because of our limited 5-yr dataset, other environments conducive to elevated severe storm wind-only cases may exist that are not described by these five cases. We recognize that five cases is inadequate to understand fully the possible types of elevated convection producing severe wind reports, but we hope that future work will further elucidate a more complete spectrum of cases.

\section{a. Case 1: Georgia, 20 November 1986}

The first case occurred on 20 November 1986 across Georgia (Fig. 6). At the surface, an east-west-oriented stationary front was present over southern parts of Alabama and Georgia (Fig. 6a), whereas a strong 500-hPa trough was centered over the Mississippi River valley (Fig. 6b), similar to the case presented by Branick et al. (1988). Cold-air damming occurred east of the Appalachians, with surface temperatures north of the stationary front in the $40 \mathrm{~s}\left({ }^{\circ} \mathrm{F}\right)\left(5^{\circ}-10^{\circ} \mathrm{C}\right)$ and easterly winds about $5 \mathrm{kt}\left(3 \mathrm{~m} \mathrm{~s}^{-1}\right)$. The 1200 UTC Centreville, Alabama (CKL), sounding showed a 50-100-hPa-deep, cool, stable layer, just above the surface (Fig. 6c). Above this frontal inversion, $500 \mathrm{~J} \mathrm{~kg}^{-1}$ of MUCAPE 

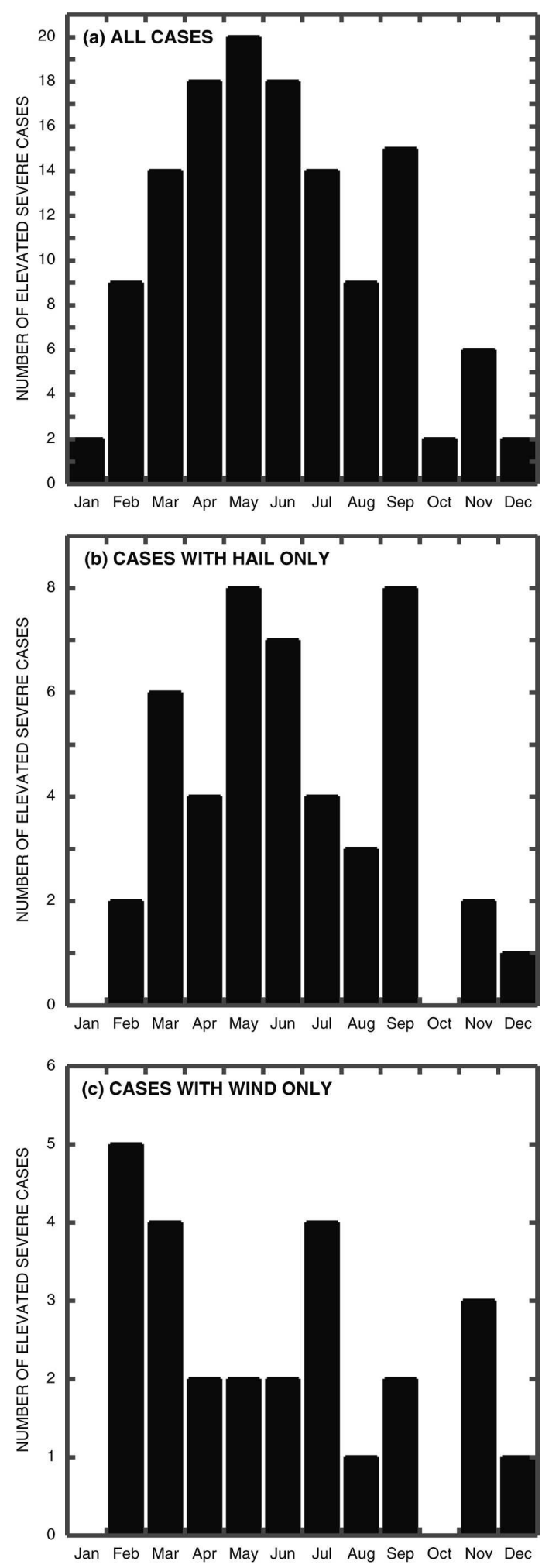

FIG. 4. Annual distribution of elevated severe storm cases compiled from the 5-yr climatology: (a) all cases, (b) cases with only hail reports, and (c) cases with only wind reports. was present with $50 \mathrm{kt}\left(26 \mathrm{~m} \mathrm{~s}^{-1}\right)$ winds or greater above $700 \mathrm{hPa}$. Dry air was also present at midlevels in the CKL sounding (Fig. 6c). Dry air at midlevels allows for evaporational cooling to occur, which can enhance strong downdraft potential and produce severe winds at the surface (e.g., Johns and Doswell 1992; Wakimoto 2001). South of the surface stationary front, warmsector MUCAPE was around $2000 \mathrm{~J} \mathrm{~kg}^{-1}$ (not shown). Composite radar maps (not shown) showed that a squall line formed in the early morning hours. This elevated squall line produced 18 severe wind damage reports across Georgia (Fig. 6d).

\section{b. Case 2: Georgia and South Carolina, 28 December 1983}

The second case occurred on 28 December 1983 across Georgia and South Carolina (Fig. 7). As in the first case, an east-west-oriented surface front lay across the southeast United States and cold-air damming occurred east of the Appalachians (Fig. 7a). A strong 500$\mathrm{hPa}$ long-wave trough was centered over the Great Plains with a well-defined short-wave trough over the lower Mississippi River valley (Fig. 7b). Surface temperatures north of the front were around freezing and easterly winds were less than $10 \mathrm{kt}\left(5 \mathrm{~m} \mathrm{~s}^{-1}\right)$. South of the front, warm-sector MUCAPE values were about $1000 \mathrm{~J} \mathrm{~kg}^{-1}$ (not shown) with temperatures in the $50 \mathrm{~s}$ $\left({ }^{\circ} \mathrm{F}\right)\left(10^{\circ}-15^{\circ} \mathrm{C}\right)$. The Athens, Georgia (AHN), sounding indicates a very strong, but shallow, inversion about 50-100 hPa above the surface (Fig. 7c), although the profile above may have been contaminated by existing convection. Winds just above the surface were around $50 \mathrm{kt}\left(26 \mathrm{~m} \mathrm{~s}^{-1}\right)$, and the strong winds were present much closer to the surface than during the 20 November 1986 case (cf. Figs. 6c and 7c), perhaps allowing for easier transport of these strong winds to the surface. A squall line was apparent from the composite radar maps (not shown) and produced 24 severe wind damage reports (Fig. 7d).

\section{c. Case 3: Mississippi, 1 February 1983}

The third case producing only wind reports occurred on 1 February 1983 in Mississippi (Fig. 8). Like the previous two cases, an east-west-oriented surface front associated with a developing surface cyclone to the west (Fig. 8a) and a strong 500-hPa trough (Fig. 8b) were present. Unlike these other two cases, however, coldair damming was not present. MUCAPE south of this warm front was $2500 \mathrm{~J} \mathrm{~kg}^{-1}$ or greater (not shown) with surface temperatures in the $60 \mathrm{~s}\left({ }^{\circ} \mathrm{F}\right)\left(15^{\circ}-20^{\circ} \mathrm{C}\right)$ and weak easterly winds. The Jackson, Mississippi (JAN), sounding possessed a 50-100-hPa-deep surface-based frontal inversion and dry air was present at midlevels 
(a) ALL SEVERE REPORTS

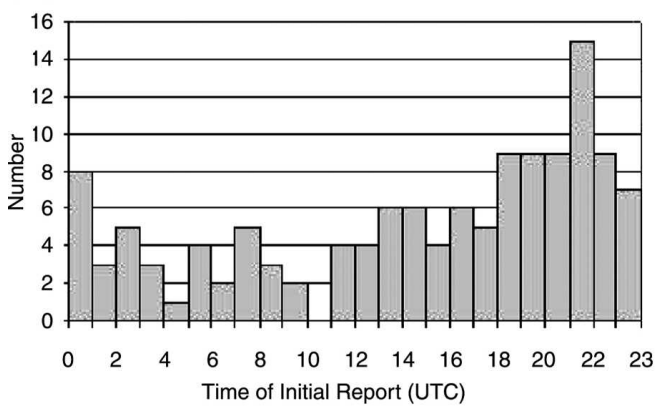

(c)

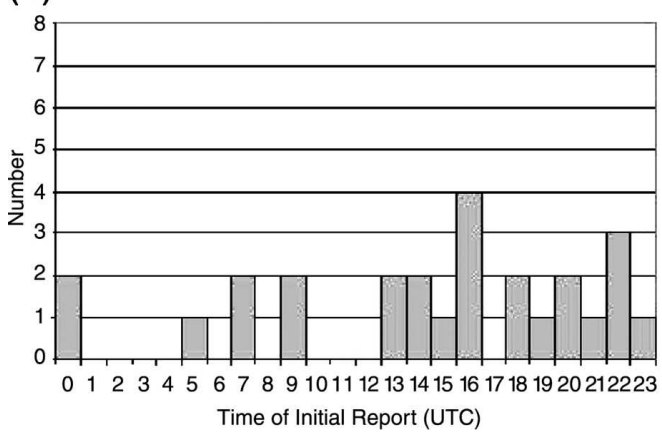

(b)

WIND/HAIL

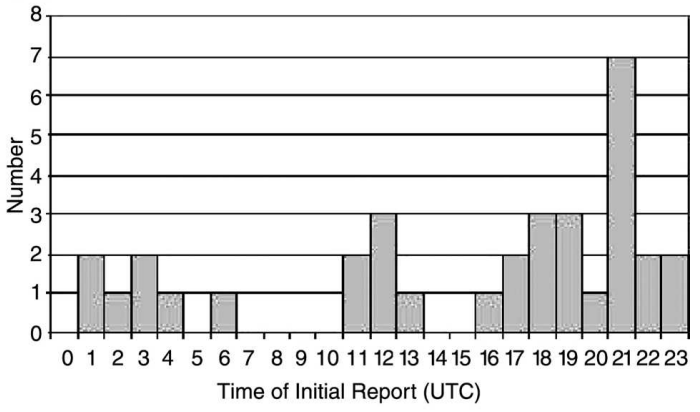

(d)

HAIL ONLY

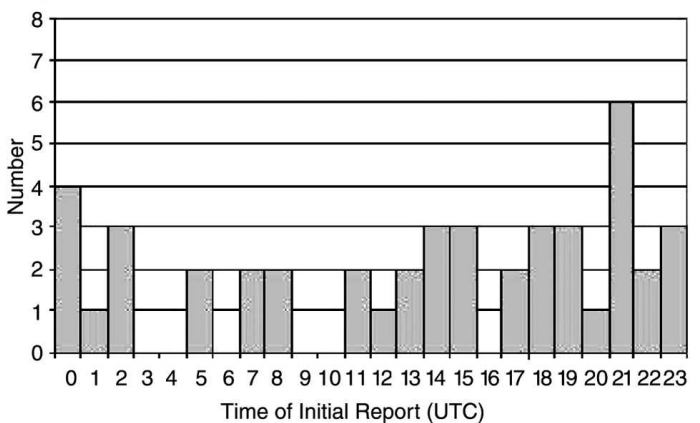

FIG. 5. Diurnal cycle of the initial elevated severe storm reports displayed for (a) all reports, (b) wind and hail both reported, (c) wind only, and (d) hail only.

(Fig. 8c). This case, however, had the strong flow confined to a somewhat greater altitude than in the previous two cases (i.e., $50 \mathrm{kt}$ or $26 \mathrm{~m} \mathrm{~s}^{-1}$ around $500 \mathrm{hPa}$ ). A squall line was analyzed from radar imagery (not shown) and on the surface map (Fig. 8a), producing four wind damage reports (Fig. 8d).

\section{d. Case 4: Iowa, 3 November 1983}

The fourth case occurred on 3 November 1983 in Iowa (Fig. 9). Surface temperatures in southern Iowa north of an east-west-oriented surface warm front were about $60^{\circ} \mathrm{F}\left(15^{\circ} \mathrm{C}\right)\left(\right.$ Fig. 9a), which is about $9^{\circ} \mathrm{F}\left(5^{\circ} \mathrm{C}\right)$ above the seasonal norm. The 500-hPa positive vorticity advection was relatively weak (Fig. 9b), especially considering that this case occurred in November. The 1200 UTC Omaha, Nebraska (OMA), sounding possessed a 50-100-hPa-deep, surface-based inversion, and dry air was present at midlevels (Fig. 9c). Near-surface winds were light and from the east and southeast (Fig. 9c). Above this inversion, there was $1000 \mathrm{~J} \mathrm{~kg}^{-1}$ MUCAPE, with convective inhibition of roughly $250 \mathrm{~J}$ $\mathrm{kg}^{-1}$. This cold-sector environment was capped to the ascent of the most-unstable parcel, unlike the first three cases. On the warm side of the front, MUCAPE values were $2000 \mathrm{~J} \mathrm{~kg}^{-1}$ or greater (not shown). The radar imagery (not shown) indicated an isolated cell, but whether it was a rotating supercell is unknown. Thus, not only is the mechanism for the strong surface winds not known, but how an elevated convective cell could form with such a strong cap in November is also an issue. We speculate that the dry air at midlevels, and resultant evaporational cooling, were important factors in producing the severe winds at the surface for this case because the winds aloft were relatively weak below $500 \mathrm{hPa}$. This case was associated with two severe wind reports (Fig. 9d).

\section{e. Case 5: Tennessee, 31 July 1986}

Unlike the other four cases, which occurred during the cool season, this case occurred on 31 July 1986 over Tennessee (Fig. 10). Radar imagery (not shown) indicated the case was associated with a mesoscale convective system (MCS). A stationary front extended from Missouri southeastward into northern Alabama (Fig. 10a). Surface temperatures across Tennessee were in the $80 \mathrm{~s}\left({ }^{\circ} \mathrm{F}\right)\left(25^{\circ}-30^{\circ} \mathrm{C}\right)$ and the surface winds had a weak westerly component. The $500-\mathrm{hPa}$ flow was northwesterly and relatively weak with a short-wave trough moving through the area (Fig. 10b), similar to a northwesterly flow, severe weather outbreak described 


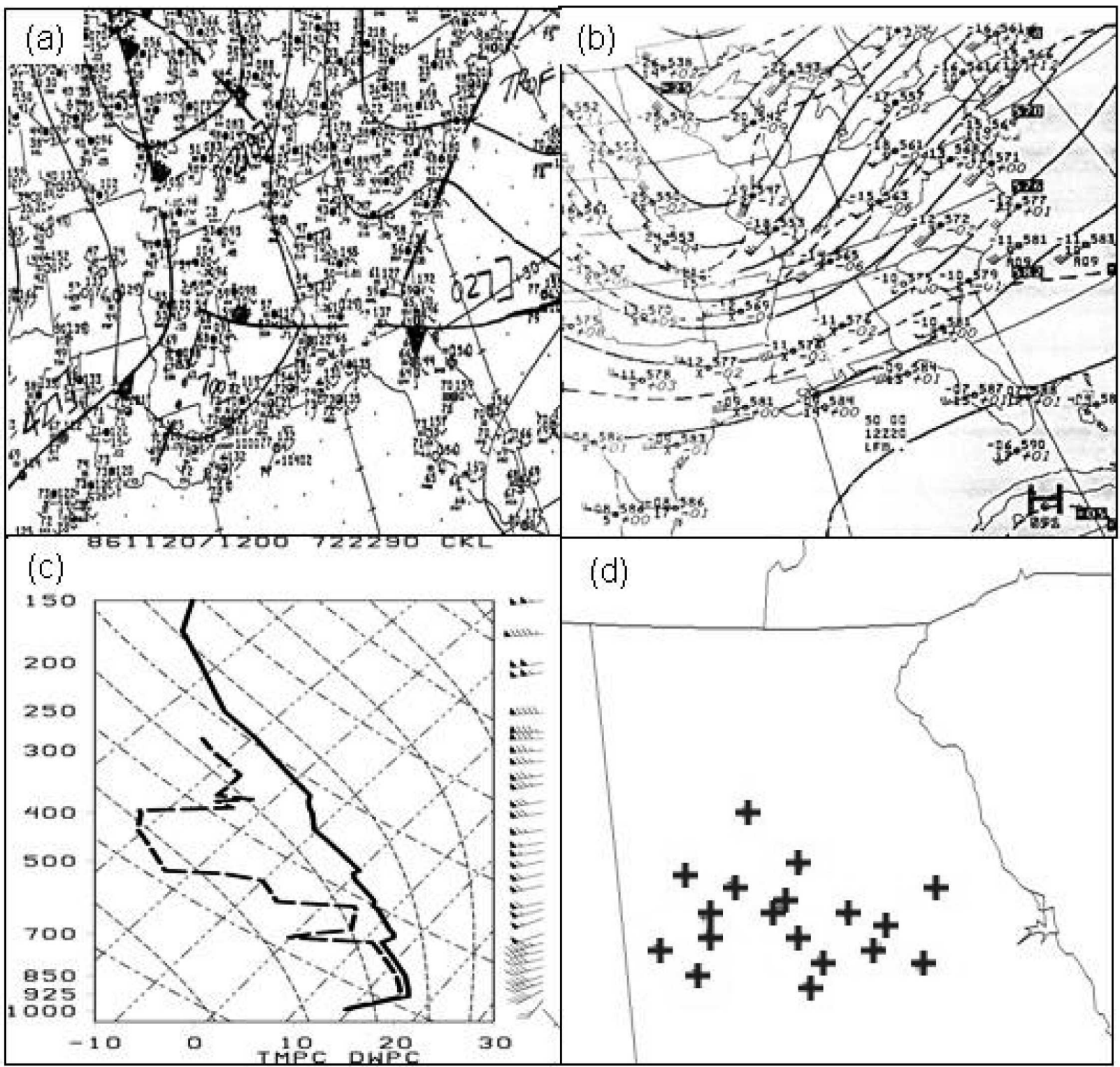

FIG. 6. Case 1, 20 Nov 1986: (a) 1200 UTC NMC surface map (station models and surface analysis are conventional), (b) 1200 UTC NMC 500-hPa map (station models are conventional), (c) 1200 UTC CKL sounding, and (d) severe wind reports (damage or measured gusts) from 1300 to 1700 UTC.

in Johns (1984, his Fig. 7). South of the stationary front in the warm sector, MUCAPE values were over $3500 \mathrm{~J}$ $\mathrm{kg}^{-1}$ (not shown). The elevated MCS formed around 0500 UTC in Illinois and moved southeast, parallel to the front. The 1200 UTC Nashville, Tennessee (BNA), sounding possessed a surface stable layer of $50 \mathrm{hPa}$ or less (Fig. 10c), possibly a nocturnal inversion, and MUCAPE of $3687 \mathrm{~J} \mathrm{~kg}^{-1}$, with near-surface dry air allowing for evaporative cooling that may have been associated with the strong surface winds. By 0000 UTC 1 August, however, the most unstable parcel in the sounding was near the ground (not shown), indicating that the MCS probably became surface based. The periods during which the MCS was elevated versus surface based were difficult to ascertain because of the lack of upper-air data around the time of the reports. There were four severe wind reports associated with this case (Fig. 10d).

\section{Discussion}

After constructing the climatology and examining the five wind-only cases, a number of questions remain un- 


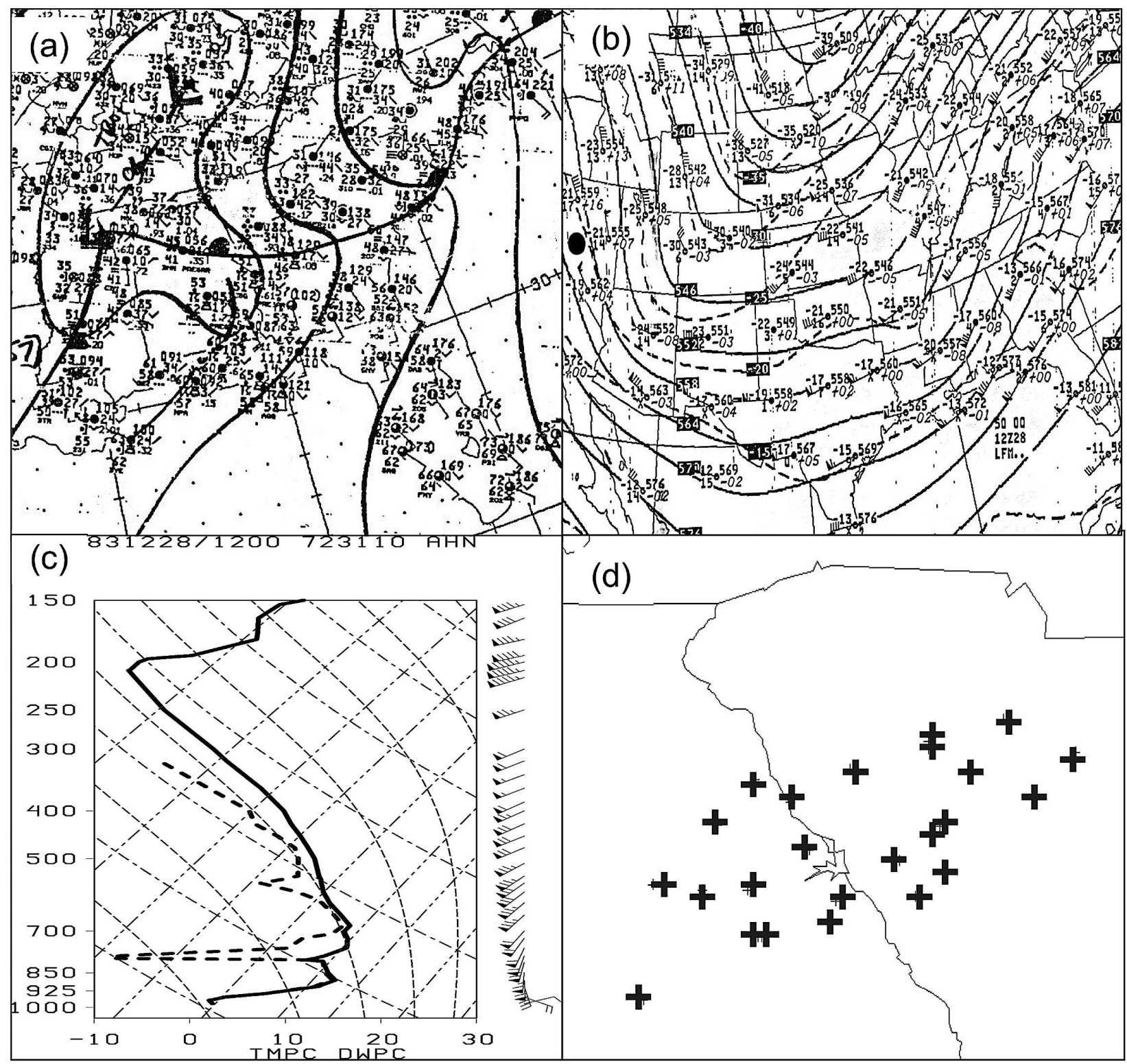

FIG. 7. Case 2, 28 Dec 1983: (a) 1200 UTC NMC surface map (station models and surface analysis are conventional), (b) 1200 UTC NMC 500-hPa map (station models are conventional), (c) 1200 UTC AHN sounding, and (d) severe wind reports (damage or measured gusts) from 1300 to 1600 UTC.

answered that affect two fundamental issues posed below. Given the nature of this research, answers to these questions require further research.

\section{a. What factors affect the production of strong surface winds?}

Given a downdraft generated by a supercell or a squall line, would the downdraft have ample kinetic energy to penetrate the environmental stable layer? Or is the environmental stable layer relevant at all? Horizontal pressure gradients caused by the surface meso- high-wake-low couplet of squall lines, for example, could also generate low-level severe winds (e.g., Branick et al. 1988; Schmidt and Cotton 1989). Horizontal buoyancy gradients may accelerate flow in from the back edge of the convective system (e.g., Weisman 1992). Surface pressure gradients associated with gravity waves moving on this low-level stable layer have also been associated with severe surface winds (e.g., Bosart and Seimon 1988; Fritsch and Forbes 2001, p. 339). What role do the surface winds play? The presence of westerly or weak easterly surface winds appears 


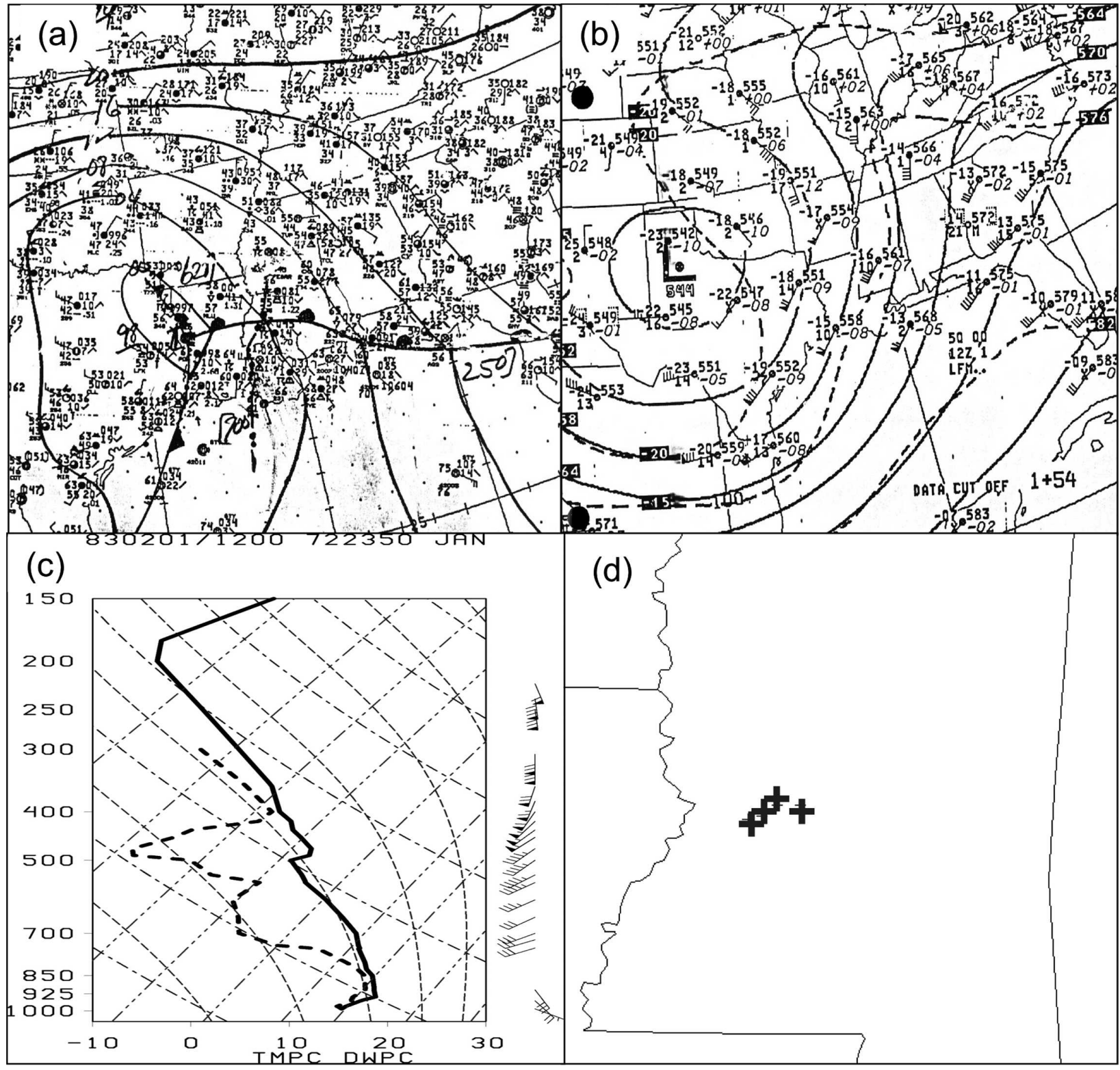

FIG. 8. Case 3, 1 Feb 1983: (a) 1200 UTC NMC surface map (station models and surface analysis are conventional), (b) 1200 UTC NMC 500-hPa map (station models are conventional), (c) 1200 UTC JAN sounding, and (d) severe wind reports (damage or measured gusts) from 0500 to 0600 UTC.

to be important in the five case studies. Are there other processes that may be responsible for the generation of strong surface winds, either by downward motion of higher-momentum air from aloft or isallobaric effects at the surface?

\section{b. How important is the strength or depth of the stable layer?}

The five wind-only cases examined showed depths of the stable layer of less than 50 to around $100 \mathrm{hPa}$, sug- gesting that deeper inversions may inhibit strong surface winds. Does a cool layer deeper than $100 \mathrm{hPa}$ prevent downdraft winds from penetrating to the surface? The small number of cases we examined prevents generalizing with any confidence.

\section{Conclusions}

A 5-yr climatology of elevated convective storms producing severe weather at the surface was con- 


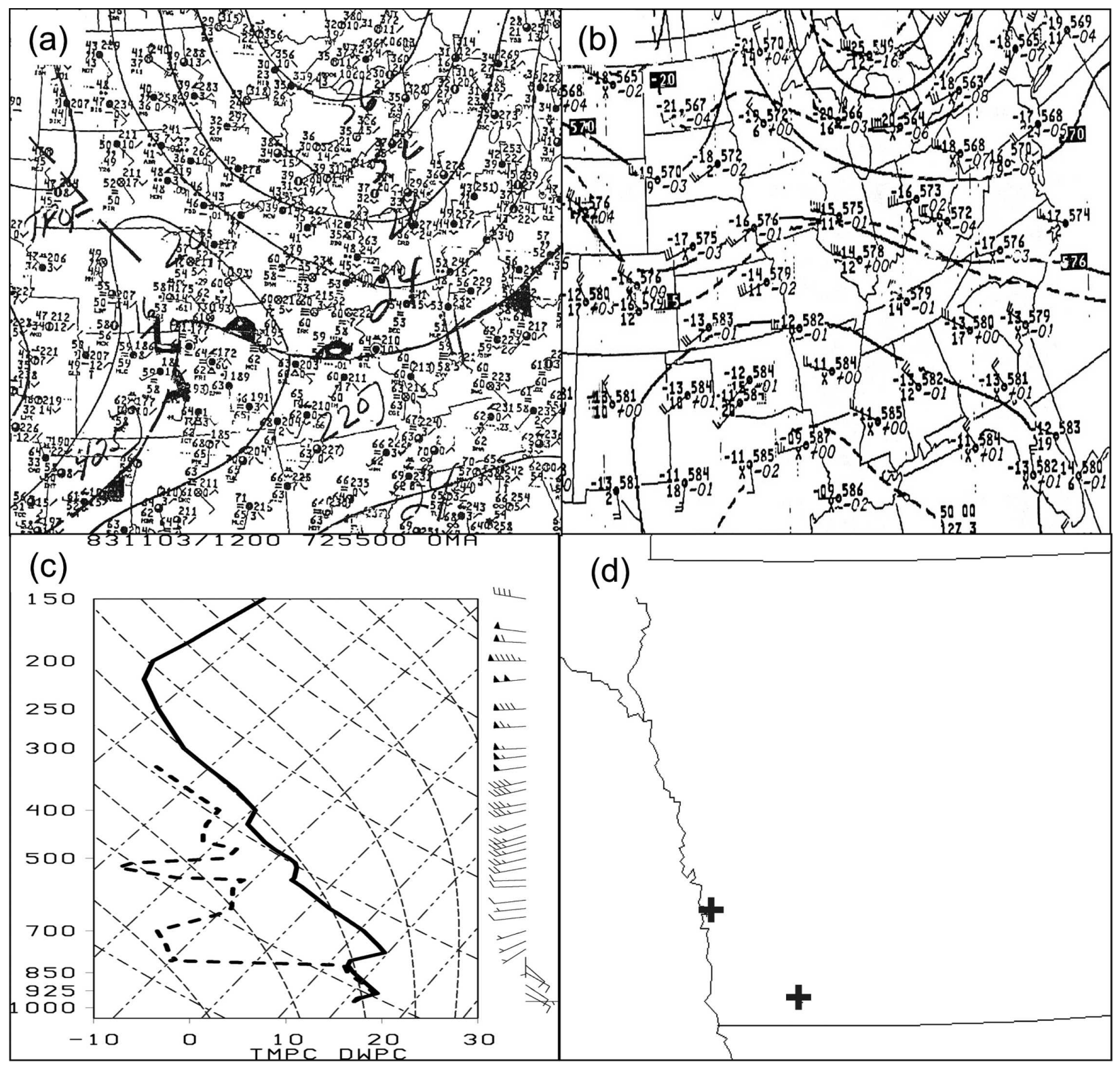

FIG. 9. Case 4, 3 Nov 1983: (a) 1500 UTC NMC surface map (station models and surface analysis are conventional), (b) 1200 UTC NMC 500-hPa map (station models are conventional), (c) 1200 UTC OMA sounding, and (d) severe wind reports (damage or measured gusts) from 1600 to 1800 UTC.

structed. In this 5-yr climatology, 1689 (91\%) of the 1826 possible days were associated with surface fronts, which were then considered for their occurrence of elevated severe storms. Of these 1689 days with surface fronts, 129 (8\%) were associated with elevated severe storm cases. The 129 elevated severe storm cases had 1066 total severe weather reports associated with them. The 1066 severe weather reports consisted of 624 $(58 \%)$ hail reports, 396 (37\%) wind reports, and 46 (4\%) tornado reports.

Elevated severe convection had an annual maximum around May with a secondary maximum in September. The geographic distribution of elevated severe convection followed the typical severe convection pattern over the central and eastern United States in the spring (March-May), the north-central and eastern United States in the summer and early fall (June-September), and the south-central United States in the late fall and winter (October-February). The diurnal maximum of the initial reports from elevated severe storm cases occurred around 2100 UTC, which coincided with the hail-only diurnal maximum. The wind-only cases had a 


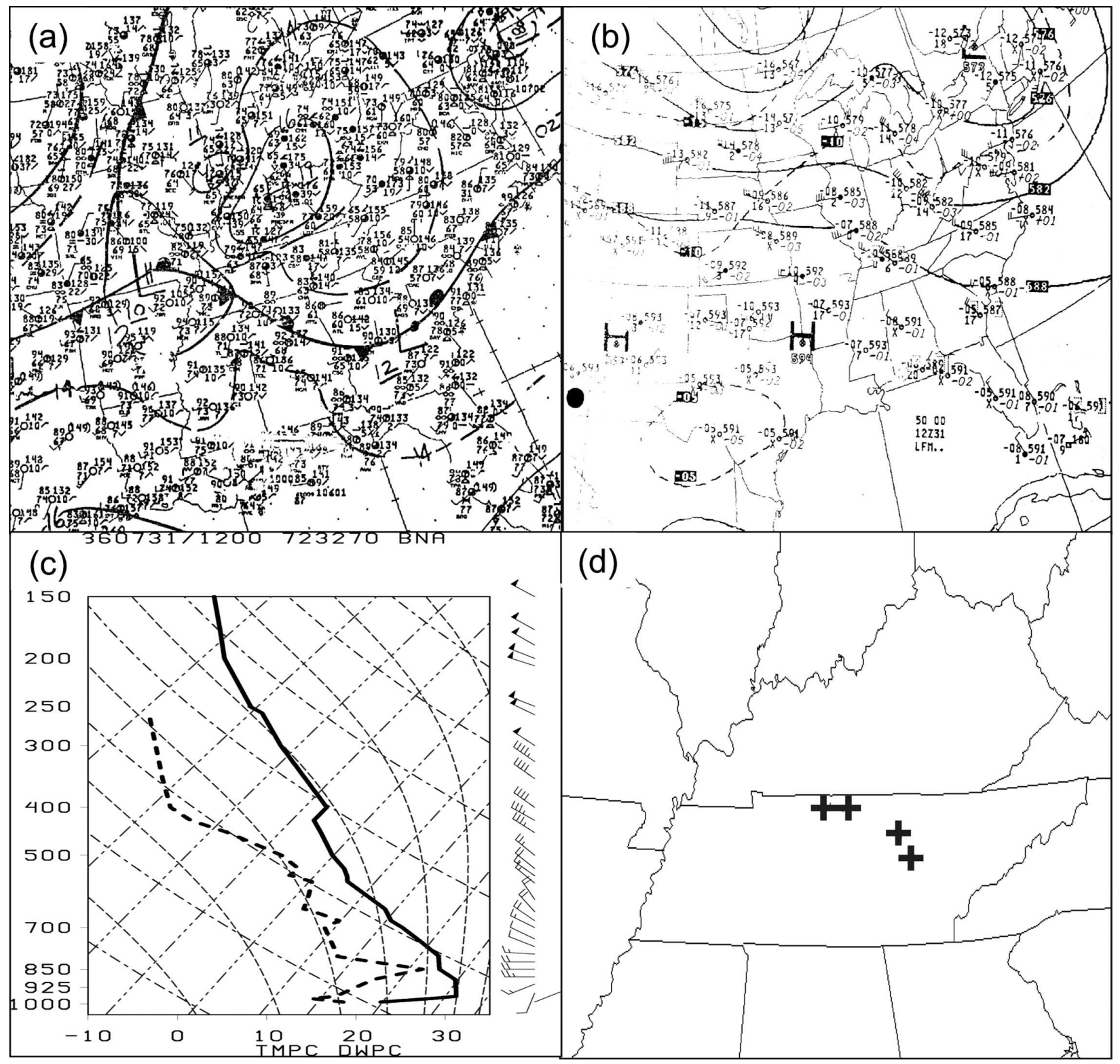

FIG. 10. Case 5, 31 Jul 1986: (a) 1500 UTC NMC surface map (station models and surface analysis are conventional), (b) 1200 UTC NMC 500-hPa map (station models are conventional), (c) 1200 UTC BNA sounding, and (d) severe wind reports (damage or measured gusts) from 1400 to 1600 UTC.

broad maximum during the daytime. Of the 129 elevated severe storm cases, 26 produced severe winds only.

Because of the difficulty in forecasting elevated convective storms that produce severe wind reports, five cases producing only wind reports were examined in greater detail. Although the number of cases is small, we believe that this study represents the beginning of a more comprehensive climatology of elevated severe storms. The first three cases, associated with deep 500$\mathrm{hPa}$ troughs and relatively weak cyclogenesis events, formed elevated convective lines. Strong winds close to the surface in two of the events appeared to be significant. A fourth case was characterized by relatively weak flow aloft and at the surface. Dry midlevel air causing evaporative cooling is believed to be important in this case. Finally, the last case was similar to the northwesterly flow outbreaks of Johns $(1982,1984)$. All cases were characterized by elevated convective available potential energy, weak surface easterlies, and shallow near-surface stable layers (less than $100 \mathrm{hPa}$ thick).

This research represents a small contribution toward 
understanding elevated severe convective storms. Certainly, scenarios other than the five cases presented are possible. Thus, future investigations should embark upon a larger climatology, especially focusing on elevated convective storms producing severe wind and/or tornado reports. With the new abundance of Aircraft Communication Addressing and Reporting System sounding profiles near airports from aircraft, a better sampling of the local thermodynamic environment of elevated convection is possible. Understanding the dynamics of strong winds at the surface from elevated convection likely requires numerical modeling of such storms. The strength and depth of the inversion, strength of the downdraft, strength of the winds above the inversion, relative humidity above the inversion, other unknown factors, or a combination of these factors may be important to the production of damaging winds at the surface, despite a near-surface stable layer.

Acknowledgments. The first author is especially grateful to John Hart for his computer software (NSHARP and SeverePlot) help and Doug Rhue for his microfilm support. Thanks to Daniel McCarthy of the SPC for providing data on the percentages of significant severe reports, and thanks to the SPC for allowing us to use their collection of surface, upper-air, and radar data on microfilm. The second author thanks Lance Bosart for his comments on this research. Pat Market, Steve Weiss, and two anonymous reviewers provided helpful comments on earlier versions of the manuscript. George Bryan provided an insightful review that improved this manuscript, including his observation that the easterly winds in the five cases were weak. We thank Daphne (Zaras) Ladue, director of the National Weather Center Research Experiences for Undergraduates (NWC REU) program, who made this study possible. The NWC REU was funded by NSF Grant 0097651. Funding for the second author was provided by NOAA/Office of Oceanic and Atmospheric Research under NOAA-University of Oklahoma Cooperative Agreement NA17RJ1227.

\section{REFERENCES}

Banacos, P. C., and D. M. Schultz, 2005: The use of moisture flux convergence in forecasting convective initiation: Historical and operational perspectives. Wea. Forecasting, 20, 351-366.

Bernardet, L. R., and W. R. Cotton, 1998: Multiscale evolution of a derecho-producing mesoscale convective system. Mon. Wea. Rev., 126, 2991-3015.

Bosart, L. F., 1989: Automation: Has its time really come? Wea. Forecasting, 4, 271.

— atmospheric gravity wave. Mon. Wea. Rev., 116, 1857-1886.
Branick, M. L., F. Vitale, C.-C. Lai, and L. F. Bosart, 1988: The synoptic and subsynoptic structure of a long-lived severe convective system. Mon. Wea. Rev., 116, 1335-1370.

Burke, P. C., and D. M. Schultz, 2004: A 4-yr climatology of coldseason bow echoes over the continental United States. Wea. Forecasting, 19, 1061-1074.

Colman, B. R., 1990a: Thunderstorms above frontal surfaces in environments without positive CAPE. Part I: A climatology. Mon. Wea. Rev., 118, 1103-1122.

_ 1990b: Thunderstorms above frontal surfaces in environments without positive CAPE. Part II: Organization and instability mechanisms. Mon. Wea. Rev., 118, 1123-1144.

_, 1991: Reply. Mon. Wea. Rev., 119, 2514-2515.

Coniglio, M. C., D. J. Stensrud, and M. B. Richman, 2004: An observational study of derecho-producing convective systems. Wea. Forecasting, 19, 320-337.

Corfidi, S. F., and K. E. Comba, 1989: The Meteorological Operations Division of the National Meteorological Center. Wea. Forecasting, 4, 343-366.

Dabberdt, W. F., and Coauthors, 2005: Multifunctional mesoscale observing networks. Bull. Amer. Meteor. Soc., 86, 961-982.

Doswell, C. A., III, H. E. Brooks, and M. P. Kay, 2005: Climatological estimates of daily local nontornadic severe thunderstorm probability for the United States. Wea. Forecasting, 20, $577-595$.

Fritsch, J. M., and G. S. Forbes, 2001: Mesoscale convective systems. Severe Convective Storms, Meteor. Monogr., No. 50, Amer. Meteor. Soc., 323-357.

Grant, B. N., 1995: Elevated cold-sector severe thunderstorms: A preliminary study. Natl. Wea. Dig., 19 (4), 25-31.

Hales, J. E., Jr., 1988: Improving the watch/warning program through use of significant event data. Preprints, 15th Conf. on Severe Local Storms, Baltimore, MD, Amer. Meteor. Soc., 165-168.

Harnack, R. P., D. T. Jensen, and J. R. Cermak, 1997: Investigation of upper-air conditions occurring with warm season severe wind events in Utah. Wea. Forecasting, 12, 282-293.

Johns, R. H., 1982: A synoptic climatology of northwest flow severe weather outbreaks. Part I: Nature and significance. Mon. Wea. Rev., 110, 1653-1663.

__ 1984: A synoptic climatology of northwest-flow severe weather outbreaks. Part II: Meteorological parameters and synoptic patterns. Mon. Wea. Rev., 112, 449-464.

_ and C. A. Doswell III, 1992: Severe local storms forecasting. Wea. Forecasting, 7, 588-612.

Mass, C. F., 1991: Synoptic frontal analysis: Time for a reassessment? Bull. Amer. Meteor. Soc., 72, 348-363.

Means, L. L., 1952: On thunderstorm forecasting in the central United States. Mon. Wea. Rev., 80, 165-189.

Moore, J. T., A. C. Czarnetzki, and P. S. Market, 1998: Heavy precipitation associated with elevated thunderstorms formed in a convectively unstable layer aloft. Meteor. Appl., 5, 373384.

- F. H. Glass, C. E. Graves, S. M. Rochette, and M. J. Singer, 2003: The environment of warm-season elevated thunderstorms associated with heavy rainfall over the central United States. Wea. Forecasting, 18, 861-878.

Rochette, S. M., and J. T. Moore, 1996: Initiation of an elevated mesoscale convective system associated with heavy rainfall. Wea. Forecasting, 11, 443-457.

—_ — , and P. S. Market, 1999: The importance of parcel choice in elevated CAPE computations. Natl. Wea. Dig., 23 (4), 20-32. 
Schaefer, J. T., J. J. Levit, S. J. Weiss, and D. W. McCarthy, 2004: The frequency of large hail over the contiguous United States. Preprints, 14th Conf. on Applied Climatology, Seattle, WA, Amer. Meteor. Soc., CD-ROM, 3.3.

Schmidt, J. M., and W. R. Cotton, 1989: A high plains squall line associated with severe surface winds. J. Atmos. Sci., 46, 281302.

Verbout, S. M., H. E. Brooks, L. M. Leslie, and D. M. Schultz, 2006: Evolution of the U.S. tornado database: 1954-2003. Wea. Forecasting, 21, 86-93.

Wakimoto, R. M., 2001: Convectively driven high wind events. Severe Convective Storms, Meteor. Monogr., No. 50, Amer. Meteor. Soc., 255-298.
Weisman, M., 1992: The role of convectively generated rearinflow jets in the evolution of long-lived mesoconvective systems. J. Atmos. Sci., 49, 1826-1847.

Weiss, S. J., J. A. Hart, and P. R. Janish, 2002: An examination of severe thunderstorm wind report climatology: 1970-1999. Preprints, 21st Conf. on Severe Local Storms, San Antonio, TX, Amer. Meteor. Soc., 446-449.

Williams, E., 1991: Comments on "Thunderstorms above frontal surfaces in environments without positive CAPE. Part I: A climatology." Mon. Wea. Rev., 119, 2511-2513.

Wilson, J. W., and R. D. Roberts, 2006: Summary of convective storm initiation and evolution during IHOP: Observational and modeling perspective. Mon. Wea. Rev., 134, 23-47. 